\title{
生細胞内の物質を検出することを指向したプローブ開発
}

\author{
柴田＼cjkstart綾
}

\section{Development of a Fluorescence Probe for Live Cell Imaging}

\author{
Aya Shibata \\ Faculty of Engineering, Gifu University; 1-1 Yanagido, Gifu 501-1193, Japan.
}

(Received June 1, 2017)

\begin{abstract}
Probes that detect specific biological materials are indispensable tools for deepening our understanding of various cellular phenomena. In live cell imaging, the probe must emit fluorescence only when a specific substance is detected. In this paper, we introduce a new probe we developed for live cell imaging. Glutathione $S$-transferase (GST) activity is higher in tumor cells than in normal cells and is involved in the development of resistance to various anticancer drugs. We previously reported the development of a general strategy for the synthesis of probes for detection of GST enzymes, including fluorogenic, bioluminogenic, and ${ }^{19} \mathrm{~F}-\mathrm{NMR}$ probes. Arylsulfonyl groups were used as caging groups during probe design. The fluorogenic probes were successfully used to quantitate very low levels of GST activity in cell extracts and were also successfully applied to the imaging of microsomal MGST1 activity in living cells. The bioluminogenic and ${ }^{19}$ F-NMR probes were able to detect GST activity in Escherichia coli cells. Oligonucleotide-templated reactions are powerful tools for nucleic acid sensing. This strategy exploits the target strand as a template for two functionalized probes and provides a simple molecular mechanism for multiple turnover reactions. We developed a nucleophilic aromatic substitution reaction-triggered fluorescent probe. The probe completed its reaction within $30 \mathrm{~s}$ of initiation and amplified the fluorescence signal from $0.5 \mathrm{pM}$ target oligonucleotide by 1500 fold under isothermal conditions. Additionally, we applied the oligonucleotide-templated reaction for molecular releasing and peptide detection.
\end{abstract}

Key words — live cell imaging; glutathione $S$-transferase; oligonucleotide sensing; oligonucleotide-templated reaction

\section{1.はじめに}

近年の画像処理技術の進歩により，細胞内の様々 な事象の可視化が可能となってきた。 それに伴い, 特定の物質のみを検出するプローブは, 細胞内の様 々な現象を理解するうえで必須の技術である．特に 生きた細胞内のイメージングを行う際には, 検出し たい物質があるときにのみ蛍光を発生するプローブ が求められている。本稿では，筆者らがこれまでに 生細胞内イメージングを指向して開発したプローブ について紹介する。

\section{GST 活性検出のための蛍光プローブの開発}

グルタチオン-S-トランスフェラーゼ (glutathione $S$-transferase; GST) は，がん細胞で過剩発現して いることが古くから知られている. 1)この GST は, 疎水性化合物（発がん性物質, 治療薬等）とグル夕

岐阜大学工学部（厂501-1193 岐阜市柳戸 1-1）

e-mail: ashibata@gifu-u.ac.jp

本総説は, 平成 28 年度日本薬学会東海支部学術奨励賞

の受賞を記念して記述したものである. チオン（glutathione; GSH）の求核置換反応を触媒 する. ${ }^{2-4)}$ この反応の結果, GSH 抱合体となつた化 合物はトランスポーターの 1 種である多剤耐性タン パク質 (multidrug resistance protein; MRP) によつ て速やかに細胞外に排出される。この GST の過剰 発現が抗がん剂耐性の一因となっているため, $1,5,6)$ 細胞内 GST 活性レベルの情報は，抗がん剂等の投 薬診断の重要な決定指針となり，いまだ不明な環境 変化に対する GST の発現調節機構の解明にも寄与 すると考えられる。

これまでにも, GST 検出のための蛍光発光プ

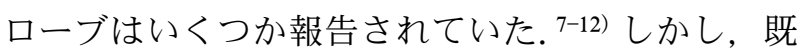
出のプローブは蛍光を発する際にプローブが GSH 抱合体となり，MRPにより速やかに細胞外に排出 されることから, 細胞内 GST の定量的検出は困難 であると予測された。一方，筆者らが開発した GST の基質となる蛍光プローブは，GSH と反応す るアリールスルフォニル保護基部と, 機能がマスク された本体から構成される. ${ }^{13-15)}$ アリールスルフォ 
(A)

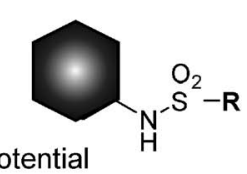

fluorogenic substrate
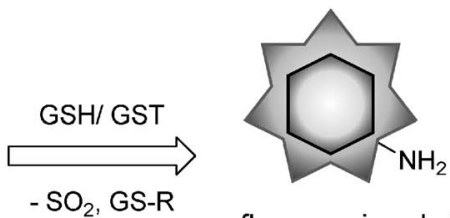

fluorogenic substrate

(B)

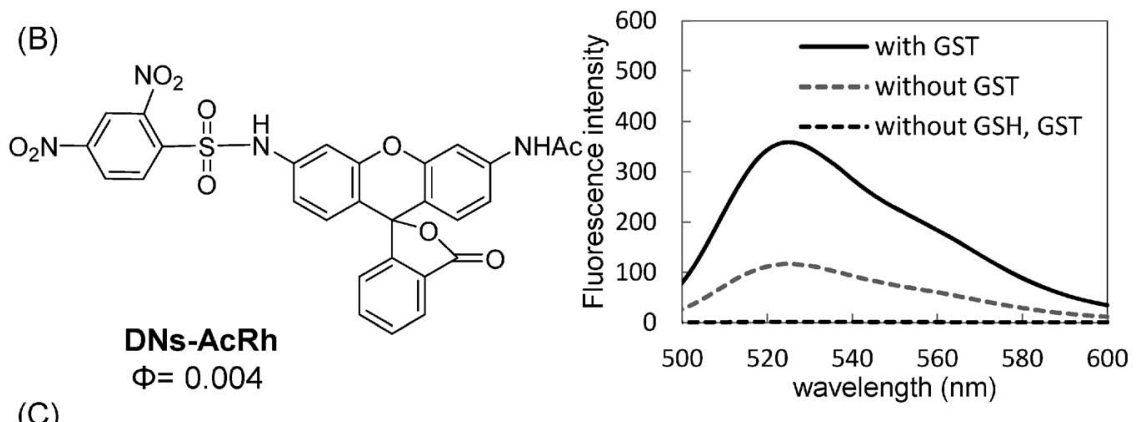

(C)
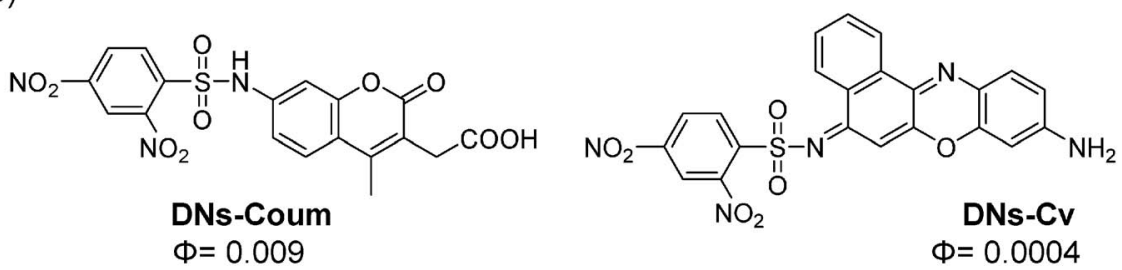

Fig. 1. (A) Potential Fluorogenic Substrates GST-catalyzed Reaction with GSH, (B) Fluorescence Measurement of the Fluorogenic Probes in the Absence or Presence of GSH/GST, and (C) Structure of DNs-Coum and DNs-CV

(B) Reactions were performed in $10 \mathrm{~mm}$ PBS (pH 7.4) with $1 \mu \mathrm{M}$ DNs-AcRh, $10 \mathrm{~mm} \mathrm{GSH}$ and $2 \mu \mathrm{g} / \mathrm{mL}$ GST for 8 min at $37^{\circ} \mathrm{C}$. $\mathrm{E}_{\mathrm{ex}}=490 \mathrm{~nm}, \mathrm{E}_{\mathrm{em}}=500-600 \mathrm{~nm}$.

Table 1. Specific Activity of GSTs with Different Fluorogenic Substrates ${ }^{\text {a }}$

\begin{tabular}{c|cccc}
\hline \multirow{2}{*}{ Enzyme } & \multicolumn{4}{|c}{$\left[k_{\text {cat }} / K_{\mathrm{m}}\right] / k_{\text {non-cat }}$} \\
\cline { 2 - 5 } Substrate & GSTA1-1 & GSTM1-1 & GSTP1-1 & MGST1 \\
\hline DNs-Coum & $(4.1 \pm 0.7) \times 10^{6}$ & $(2.3 \pm 0.6) \times 10^{6}$ & $(1.5 \pm 0.5) \times 10^{6}$ & $(3.2 \pm 0.9) \times 10^{5}$ \\
DNs-AcRh & $(6.8 \pm 0.6) \times 10^{7}$ & $(1.1 \pm 0.2) \times 10^{7}$ & $(8.0 \pm 1.8) \times 10^{6}$ & $(1.9 \pm 0.4) \times 10^{7}$ \\
DNs-CV & $(2.4 \pm 1.1) \times 10^{9}$ & $(3.6 \pm 2.1) \times 10^{8}$ & $(3.6 \pm 2.1) \times 10^{8}$ & $(4.3 \pm 1.2) \times 10^{8}$ \\
\hline
\end{tabular}

a Specific activities were obtained in $0.1 \mathrm{~m}$ potassium phosphate buffer $\mathrm{pH} 6.5$ (with $0.1 \%$ Triton for MGST1), $5 \mathrm{~mm}$ GSH and DNsCoum, DNs-AcRh, DNs-CV as second substrate. The concentration of DNs-Coum used was $40 \mu \mathrm{m}$, the concentration of DNs-AcRh used was $25 \mu \mathrm{M}$, and the concentration of DNs-CV used was $2.5 \mu \mathrm{M}$. The final DMSO concentration in all assays was $1.0 \%(\mathrm{v} / \mathrm{v})$.

ニル保護プローブが細胞内に導入されると，プロー ブに対し GSH が GST を触媒として求核置換攻撃 を行う。この芳香族求核置換反応の結果，プローブ から保護基が除去され，蛍光シグナルが発生する [Fig. 1(A)]。この反応のときに，プローブ自身は GSH 修飾を受けないことから細胞内で安定してシ グナルを発生することが可能となる.

まずはじめに，ジニトロベンゼンスルフォニルク ロリドと蛍光基質であるモノアセチルローダミン (mono-acetyl rhodamine; AcRh) を反応させること で，DNs-AcRh を合成した。得られた DNs-AcRh は単体では水溶液中でほぼ無蛍光であるのに対し,

GSH のみ若しくは GSH/GST で処理すると $520 \mathrm{~nm}$
付近にローダミン由来の蛍光が観測された $[\mathrm{Fig} .1$ (B) ].このとき, GST 存在下でのほうが蛍光の回 復が大きかったことから，プローブに対する GSH の求核攻撃は GST 存在下で促進することが分かっ た。この結果より，DNs-AcRh は GSH/GST 活性 を検出することが可能であること示された．さらに この手法が他の蛍光基質にも応用可能であるかを検 討したところ, クマリンやクレシルバイオレットに も DNs 基を導入することで同様に GST 検出プロー ブを得ることに成功した $[$ Fig. 1(C)]。これらプ ローブを用いて，各種 GST のサブタイプに対する 反応性について検討を行ったところ，合成したプ ローブは，特に GSTA1-1 に対し高い特異性を示す 


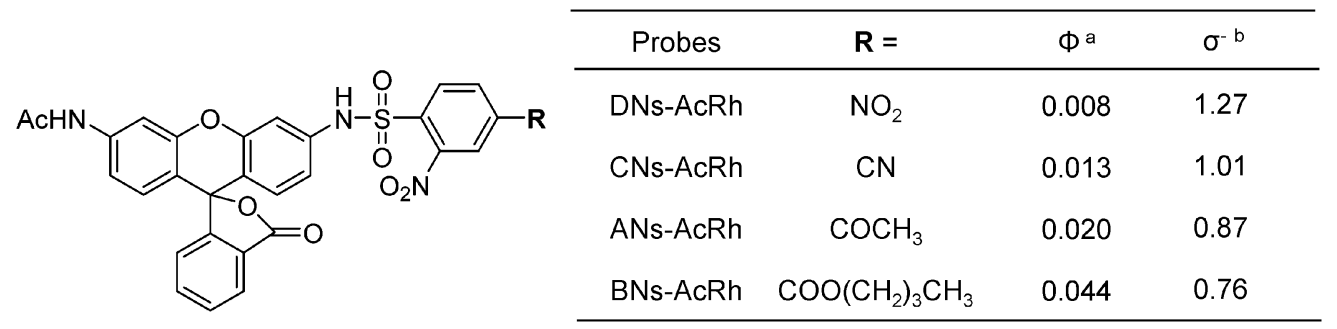

Fig. 2. Quantum Yields of 4-Substituted-2-nitorobenzeneslufonyl Protected AcRh Probes

a All measurements were done in PBS $(\mathrm{pH} \mathrm{7.4,100} \mathrm{mM).} \mathrm{Compounds} \mathrm{were} \mathrm{excited} \mathrm{at} 490 \mathrm{~nm}$. Quantum yields are determined by using fluorescein $(\Phi=0.85$, $0.1 \mathrm{M} \mathrm{NaOH})$ as a standard. ${ }^{\mathrm{b}}$ Hammett constants $\left(\sigma^{-}\right)$were taken from Ref. 19) and 21).

Table 2. Steady-state Kinetic Parameters of GST with 4-Substetuted-2-nitrobenzenslufonyl Protected AcRh ${ }^{\text {a }}$

\begin{tabular}{|c|c|c|c|c|c|}
\hline & & wo GST & GSTA1-1 & GSTM2-2 & GSTP1-1 \\
\hline DNs & $\begin{array}{c}K_{\mathrm{m}}(\mu \mathrm{M}) \\
k_{\text {cat }}\left(\times 10^{-1} \mathrm{~s}^{-1}\right) \\
k_{\text {cat }} / K_{\mathrm{m}}\left(\times 10^{4} \mathrm{M}^{-1} \mathrm{~s}^{-1}\right) \\
k_{\text {non-cat }}\left(\mathrm{M}^{-1} \mathrm{~s}^{-1}\right) \\
\text { rate enhancement }\left(\times 10^{4}\right)^{\mathrm{b}}\end{array}$ & $5.56 \pm 0.97$ & $\begin{array}{r}2.43 \pm 0.18 \\
150.22 \pm 7.99 \\
618.6 \pm 24.4 \\
\\
111.3 \pm 4.4\end{array}$ & $\begin{array}{c}4.70 \pm 0.26 \\
24.59 \pm 1.27 \\
52.4 \pm 1.0 \\
9.4 \pm 0.2\end{array}$ & $\begin{array}{r}7.42 \pm 1.95 \\
15.28 \pm 3.68 \\
20.7 \pm 0.5 \\
3.7 \pm 0.1\end{array}$ \\
\hline $\mathrm{CNs}$ & $\begin{array}{c}K_{\mathrm{m}}(\mu \mathrm{M}) \\
k_{\text {cat }}\left(\times 10^{-1} \mathrm{~s}^{-1}\right) \\
k_{\text {cat }} / K_{\mathrm{m}}\left(\times 10^{4} \mathrm{M}^{-1} \mathrm{~s}^{-1}\right) \\
k_{\text {non-cat }}\left(\mathrm{M}^{-1} \mathrm{~s}^{-1}\right) \\
\text { rate enhancement }\left(\times 10^{4}\right)^{\mathrm{b}}\end{array}$ & $3.60 \pm 0.16$ & $\begin{array}{r}3.21 \pm 0.26 \\
113.62 \pm 7.98 \\
354.7 \pm 6.2 \\
\\
98.5 \pm 1.7\end{array}$ & $\begin{array}{c}4.92 \pm 0.79 \\
20.85 \pm 1.86 \\
42.8 \pm 3.0 \\
11.9 \pm 0.8\end{array}$ & $\begin{array}{c}4.15 \pm 0.40 \\
8.84 \pm 0.64 \\
21.4 \pm 0.8 \\
5.9 \pm 0.2\end{array}$ \\
\hline ANs & $\begin{array}{c}K_{\mathrm{m}}(\mu \mathrm{M}) \\
k_{\text {cat }}\left(\times 10^{-1} \mathrm{~s}^{-1}\right) \\
k_{\text {cat }} / K_{\mathrm{m}}\left(\times 10^{4} \mathrm{M}^{-1} \mathrm{~s}^{-1}\right) \\
k_{\text {non-cat }}\left(\mathrm{M}^{-1} \mathrm{~s}^{-1}\right) \\
\text { rate enhancement }\left(\times 10^{4}\right)^{\mathrm{b}}\end{array}$ & $1.45 \pm 0.06$ & $\begin{array}{c}7.99 \pm 1.62 \\
47.81 \pm 8.81 \\
60.1 \pm 2.1 \\
41.5 \pm 1.4\end{array}$ & $\begin{array}{c}7.67 \pm 1.21 \\
18.36 \pm 3.98 \\
23.8 \pm 2.3 \\
16.5 \pm 1.6\end{array}$ & $\begin{array}{l}6.65 \pm 0.93 \\
7.07 \pm 0.89 \\
10.7 \pm 0.3 \\
7.4 \pm 0.2\end{array}$ \\
\hline $\mathrm{BNs}$ & $\begin{array}{c}K_{\mathrm{m}}(\mu \mathrm{M}) \\
k_{\text {cat }}\left(\times 10^{-1} \mathrm{~s}^{-1}\right) \\
k_{\text {cat }} / K_{\mathrm{m}}\left(\times 10^{4} \mathrm{M}^{-1} \mathrm{~s}^{-1}\right) \\
k_{\text {non-cat }}\left(\mathrm{M}^{-1} \mathrm{~s}^{-1}\right) \\
\text { rate enhancement }\left(\times 10^{4}\right) \mathrm{b}\end{array}$ & $0.39 \pm 0.02$ & $\begin{array}{l}1.04 \pm 0.06 \\
5.65 \pm 0.06 \\
54.6 \pm 2.9 \\
138.7 \pm 7.3\end{array}$ & $\begin{array}{l}0.80 \pm 0.14 \\
1.85 \pm 0.03 \\
23.8 \pm 4.3 \\
60.6 \pm 10.8\end{array}$ & $\begin{array}{l}0.66 \pm 0.22 \\
0.70 \pm 0.05 \\
11.4 \pm 2.5 \\
29.1 \pm 6.3\end{array}$ \\
\hline
\end{tabular}

a The GST (GSTA1-1, GSTM2-2, or GSTP1-1) was assayed in 0.1 м potassium phosphate buffer pH 6.5, at 5 mM constant GSH and varying concentrations of DNs-AcRh $(1-10 \mu \mathrm{M})$, CNs-AcRh $(1-10 \mu \mathrm{M})$, ANs-AcRh $(1-30 \mu \mathrm{M})$, or BNs-AcRh $(1-50 \mu \mathrm{M})$. The final concentration of the solvent DMSO was $1 \%$. Values are means \pm S.E. of the mean $(n=3) \cdot{ }^{\mathrm{b}}$ Rat enhancement $=\left(k_{\text {cat }} / K_{\mathrm{m}}\right) / k_{\text {non-cat }}$.

ことが明らかとなった（Table 1)。特に DNs 保護 クレシルバイオレット（DNs-Cv）は GST 非存在 下と比較してその反応効率が $2.4 \times 10^{9}$ 倍に増加す ることが確認できた. ${ }^{14)}$

一般的に芳香族求核置換反応は置換基の電子吸引 性によって反応性が異なることが知られている. GST 検出プローブにおいても，過去に 1-chloro2,4-dinitrochlorobenzene (CDNB) の 2 位若しくは 4 位の置換基を変えて GSH/GST との反応性を検討 した報告がなされている. ${ }^{16-20)}$ それらの論文では ラット由来の GST が触媒する GSH と 2 位若しく
は 4 位置換 CDNB アナログとの反応は，一部の例 外はあるものの，ハメットの置換基定数 $\left(\sigma^{-}\right)$に 比例することが示されている，そこで筆者らも，ア リールスルフォニル基に求電子性の異なる様々な置 換基を導入し，各種アリールスルフォニル基で保護 したプローブと GST の反応性について検討を行つ た (Fig. 2 and Table 2). 得られた結果を基に, 触 媒効率 $\left(k_{\mathrm{cat}} / K_{\mathrm{m}}\right)$ と $\sigma^{-}$をグラフにプロットしたと ころ, $k_{\mathrm{cat}} / K_{\mathrm{m}}$ と $\sigma^{-}$との間には直線性が示された が，GST のサブタイプによって置換基の影響は異 なることが明らかとなった（Fig. 3)。GSTA1-1 が 

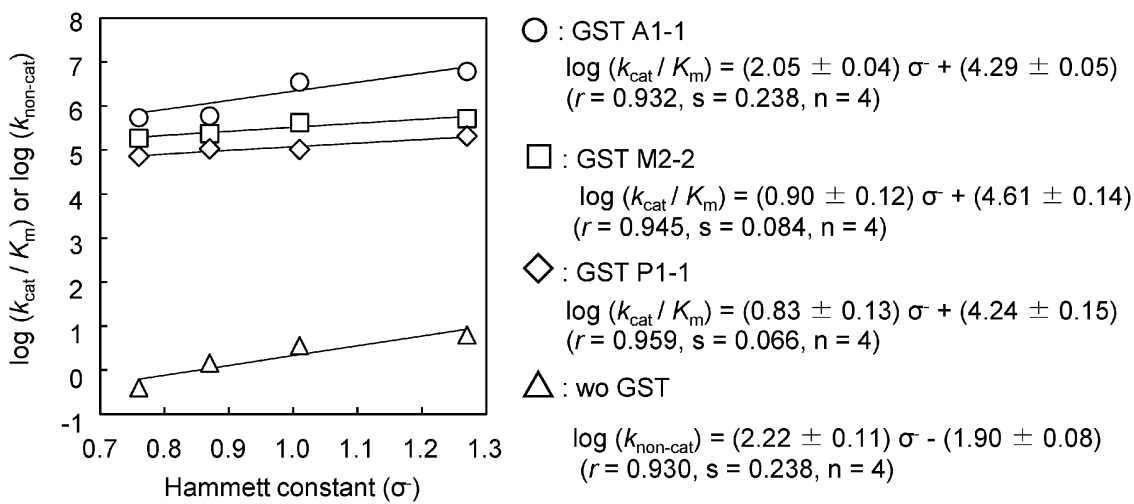

Fig. 3. Hammett Plot of $\log \left(k_{\mathrm{cat}} / K_{\mathrm{m}}\right)$ or $\log \left(k_{\text {non-cat }}\right)$ vs. $\sigma$ for Non-enzyme or Enzyme-catalyzed Reaction Hammett constant are from Fig. 2 and value of $k_{\text {cat }} / K_{\mathrm{m}}$ and $k_{\text {non-cat }}$ are from Table 2. Lines are least-square fits to the data points by Microsoft Excel.
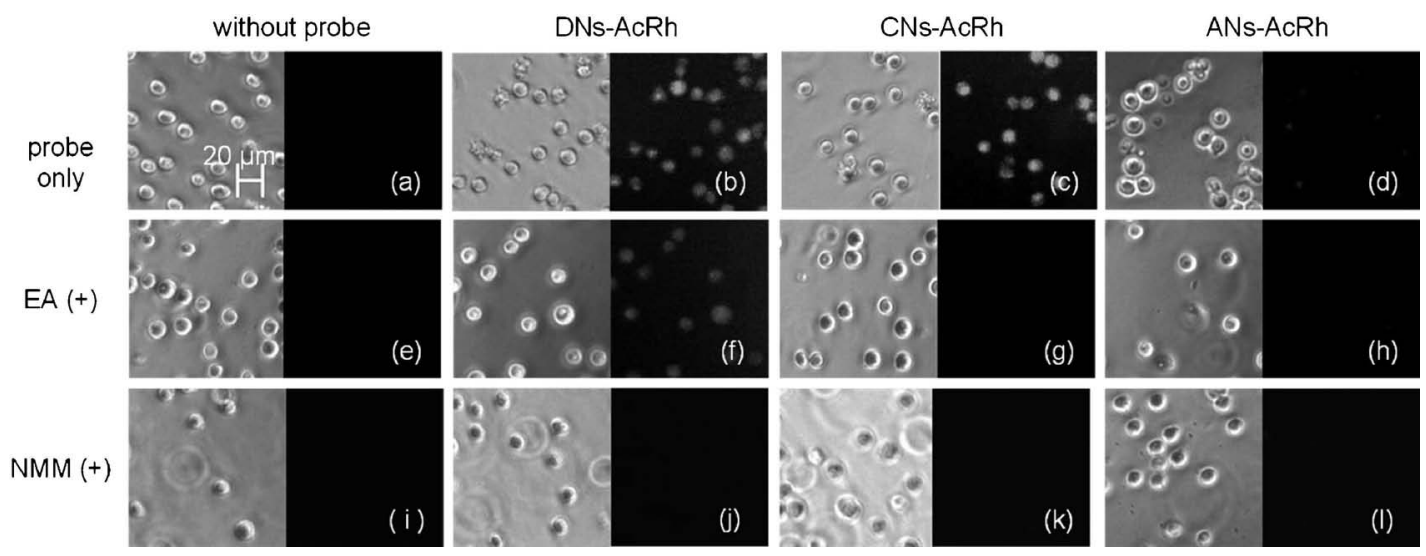

Fig. 4. Fluorescence Image of HL-60 Cells

(a-d) Image of cells incubated with $10 \mu \mathrm{M}$ probe for $60 \mathrm{~min}$ at $37^{\circ} \mathrm{C}$. (e-l) Control image of cells pretreated with (e-h) $50 \mu \mathrm{M}$ EA or (i-l) $1 \mathrm{mM}$ NMM for 60 min at $37^{\circ} \mathrm{C}$ and then incubated with $10 \mu \mathrm{M}$ probe for $60 \mathrm{~min}$ at $37^{\circ} \mathrm{C}$. (left) Bright field image; (right) Fluorescence image. Microscope settings were as follows: excitation: 470/40 bandpass filter; emission: 525/50 bandpass filter.

触媒する反応では，結合している置換基の電子吸引 性は GST 非存在下での芳香族求核置換反応と同程 度影響することが分かった。この結果は, GSTA11 が触媒する反応では一般的な芳香族求核置換反応 と同様に Meisenheimer 錯体の形成が律速であるこ とを示している。一方で GSTM2-2 や P1-1 が触媒 する反応では反応に対する置換基の電子吸引性の影 響は小さいものに留まることが分かった．X 線構 造解析から，GSTM2-2やP1-1 は触媒部位にチロ シン残基を持ち, このチロシン残基が 2 位のニトロ 基と水素結合することで遷移状態を安定化すること が分かっている. ${ }^{22)}$ そのため，この結果は Meisenheimer 錯体がチロシン残留物によって安定したた め, 4 位の置換基を変化させても錯体形成の安定化 に影響をほとんど及ぼさなかったことに起因すると 考えられる.

DNs-AcRh, CNs-AcRh 及び ANs-AcRh を用いて
生細胞内の GSH/GST 活性のイメージングを試み た（Fig. 4). 結果，プローブのみを添加した細胞 では，DNs-AcRh 若しくは CNs-AcRh を用いた場 合には，強い蛍光が観察されたが，ANs-AcRh を 用いた場合には蛍光はほとんど観察されなかった。

一方で, GST 阻害剂であるエタクリン酸 (ethacrynic acid; EA) 23) であらかじめ処理した細胞 にプローブを添加した場合には，DNs-AcRh を用 いた場合にのみ蛍光が観察された。また, GSH の ブロッキング剂である $N$-メチルマレイミド（Nmethylmaleimide; NMM） で処理した細胞ではいず れのプローブを用いた場合でも，蛍光は観察されな かった．以上のことから，DNs-AcRh は細胞内の GSH のみでも反応してしまうことが分かった。そ れに対し，CNs-AcRh は GST 活性がある細胞での 夕蛍光を発生させたことから，生細胞内の GST 活 性を検出するのに適したプローブであることが分 


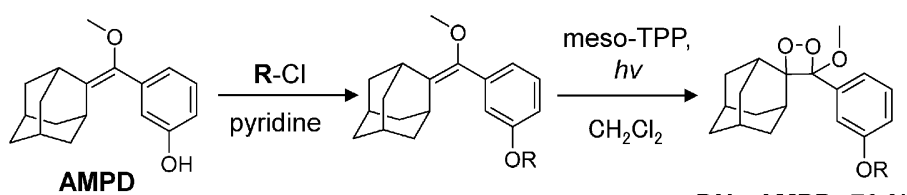

DNs-AMPD: $70 \%$

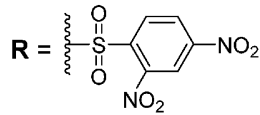

DNs

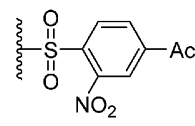

ANs

ANs-AMPD: $93 \%$

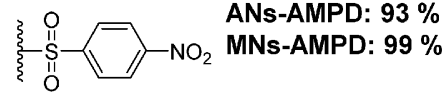

MNs

Scheme 1. Synthetic Scheme of Chemiluminogenic Probe

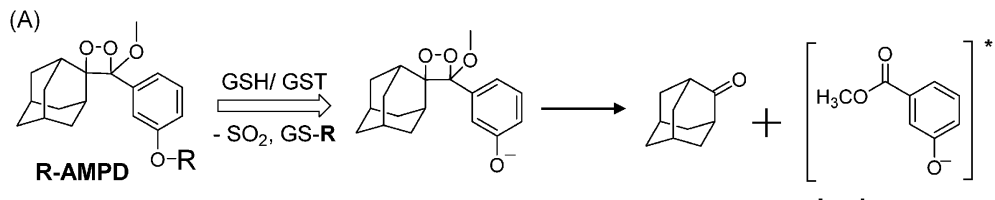

(B)

\begin{tabular}{cccc}
\hline substrate & with GST & without GST & S/B $^{\text {a }}$ \\
\hline DNs-AMPD & 2618 & 1946 & 1.3 \\
ANs-AMPD & 1583 & 55 & 28.8 \\
MNs-AMPD & 43 & 14 & 3.1 \\
\hline
\end{tabular}

Fig. 5. (A) Mechanism of Chemiluminogenic Probes for GST Detection, and (B) Luminescence Measurement in the Absence or Presence of GST

(B) Reactions were performed in $10 \mathrm{~mm}$ PBS (pH 7.4, $1 \%$ DMSO as a cosolvent) with $50 \mu \mathrm{m}$ probe, $1 \mathrm{~mm} \mathrm{GSH}$, and 0 or $10 \mu \mathrm{g} / \mathrm{mL}$ GST ( $\alpha$ and $\mu$ mixture) for $60 \mathrm{~min}$ at room temperature. a S/B ratios were calculated based on signal intensity in the presence or absence of GST.

かった.

3. GST 活性を引き金とする化学発光プローブ, ${ }^{19}$ F-NMR プローブ及びプロドラッグの開発

筆者らが開発したアリールスルフォニル基を制御 ユニットとして用いる GST 活性検出プローブの戦 略は他のシグナル発生分子にも容易に応用できる. そこで次に, GST 活性検出プローブとして, 化学 発光プローブと ${ }^{19} \mathrm{~F}-\mathrm{NMR}$ プローブの開発を試み た. ${ }^{24)}$ また，抗がん剂のプロドラッグ化への応用も 併せて検討を行った. ${ }^{25)}$

生物発光プローブの合成は, Scheme 1 に示すよ うに発光ユニットとして用いるアダマンタニル 1,2ジオキセタン基を有するフェノール誘導体 (AMPD) 26-29) を合成したのちに水酸基に制御ユ ニットであるアリールスルフォニル基を導入するこ とで行った。このとき，アリールスルフォニル基が 異なる 3 つの分子を合成した. Figure 5(A) に示す ように，アリールスルフォニル保護 AMPD（RAMPD）は，GST/GSH と反応することにより不 安定な中間体が形成される。この中間体は速やかに 分解され，ジオキセタンの開裂と同時に $470 \mathrm{~nm}$ の
発光を示す. 合成した発光プローブの GST 検出能 を検討した結果，4-アセチル-2-ニトロベンゼンス ルフォニル基（ANs）で保護した ANs-AMPD のシ グナル/バックグラウンド (S/B) 比が最も大きく, 生物発光プローブとして有用であることが示された [Fig. 5(B) ]. ANs-AMPD を用いて各種 GST サブ タイプ (GSTA1-1, GSTM2-2, GSTP1-1, MGST1) に対する酵素反応速度をミカエリスメンテンの式に より解析した（Table 3)。 その結果，ANs-AMPD は GSTA1-1 に対して高い反応性を示し，その反応 速度は GST 非存在下と比較し約 $10^{6}$ 倍に増大し た。 次に, 大腸菌細胞を用いて細胞内 GST 検出を 検討した（Fig. 6)。GST を発現している大腸菌培 養液中に ANs-AMPD を添加したところ，顕著な生 物発光シグナルが生じた。一方，GST を発現して ない大腸菌では, 生物発光は検出されなかった。こ の結果は, ANs-AMPD が細胞膜透過性であり, 生 細胞中の GSH/GST と反応することで自動発光す ることを示している.ANs-AMPD/GSH/GST を用 いた系はルシフェリン/ルシフェラーゼの系と同様 な生物発光システムとしての利用が期待される. 
Table 3. Steady-state Kinetic Parameters of GST with ANs-AMPD

\begin{tabular}{llllll}
\hline \hline \multirow{2}{*}{ Parameters } & \multicolumn{4}{c}{ Enzyme } \\
\cline { 3 - 6 } & & \multicolumn{1}{c}{ GSTA1-1 } & \multicolumn{1}{c}{ GSTM1-1 } & GSTP1-1 & MGST1 \\
\hline \multirow{2}{*}{ ANs-AMPD } & $K_{\mathrm{m}}(\mu \mathrm{M})$ & $24 \pm 6.1$ & $2.8 \pm 0.53$ & $3.7 \pm 0.59$ & $13 \pm 3.6$ \\
& $k_{\text {cat }}\left(\mathrm{s}^{-1}\right)$ & $(27 \pm 5.5) \times 10^{-3}$ & $(0.6 \pm 0.09) \times 10^{-3}$ & $(0.9 \pm 0.7) \times 10^{-3}$ & $(7 \pm 1) \times 10^{-3}$ \\
& $k_{\text {cat }} / K_{\mathrm{m}}\left(\mathrm{M}^{-1} \mathrm{~s}^{-1}\right)$ & $(11 \pm 0.6) \times 10^{2}$ & $(2.4 \pm 0.1) \times 10^{2}$ & $(2.0 \pm 0.07) \times 10^{2}$ & $(5.1 \pm 0.4) \times 10^{2}$ \\
& rate enhancement & $(11 \pm 0.6) \times 10^{5}$ & $(2.4 \pm 0.1) \times 10^{5}$ & $(2.0 \pm 0.07) \times 10^{5}$ & $(17.5 \pm 1.0) \times 10^{5}$ \\
\hline
\end{tabular}

The cytosolic GST (GSTA1-1, GSTM1-1 or GSTP1-1) was assayed in 0.01 м PBS (pH 7.4), at a constant GSH concentration of 1 mM and varying concentrations of ANs-AMPD $(0.156-80 \mu \mathrm{M})$. Whereas MGST1 was assayed in $0.01 \mathrm{~m}$ PBS (pH 7.4) with $0.05 \%$ Triton, at a constant GSH concentration of $1 \mathrm{~mm}$ and varying concentrations of ANs-AMPD $(0.5-100 \mu \mathrm{M})$. The final concentration of the solvent DMSO was $10 \%(\mathrm{v} / \mathrm{v})$. Error limits are given by Graphpad Prism 5 after fitting by non-linear regression; in general at least 15 observations were included in the datasets. Rate enhancements produced by GSTs. Values are means \pm S.E.M. of $k_{\text {cat }} / K_{\mathrm{m}}$ divided by $k_{\text {non-cat }}$.

(A)

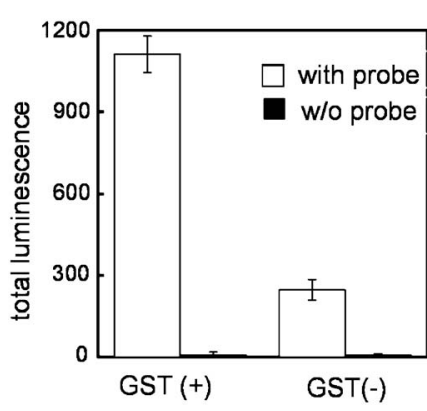

(B)

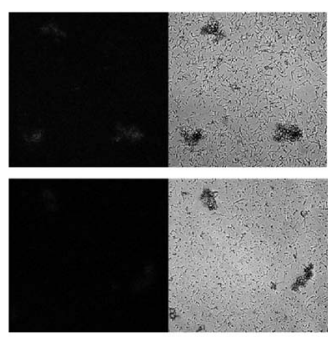

Fig. 6. (A) Detection of GST Activity Using ANs-AMPD in the E. coli of GST Expression or Nonexpression, and (B) Detection of Intracellular GST in the E. coli by Fluorescence Microscopy

(A) Reactions were performed in E. coli cells [the value of O.D 600 was adjusted 1.4 in $10 \mathrm{~mm}$ PBS (pH 7.4, 0.6\% DMSO as a cosolvent)] with 50 $\mu \mathrm{M}$ probe and $1 \mathrm{~mm}$ GSH for $60 \mathrm{~min}$ at room temperature. (B) Reactions were performed in $E$. coli cells [the value of O.D D $_{600}$ was adjusted 1.4 in 10 mм PBS (pH 7.4, 0.6\% DMSO as a cosolvent)] with $250 \mu \mathrm{M}$ probe and 1 mM GSH for $6 \mathrm{~h}$ at room temperature. Top: ANs-AMPD probe in $E$. coll (GST expression), bottom: ANs-AMPD probe in E. coli (no GST expression), left: luminescent signal only, right: bright field image.

核磁気共鳴画像法（MRI）は感度及び解像度に おいては蛍光プローブに劣るが，個体深部での観測 が可能なことから診断技術として有用である. ${ }^{30)}$ ま た， ${ }^{19} \mathrm{~F}$ 核は生体内でほとんど存在しないことから， $\mathrm{S} / \mathrm{B}$ 比の高い観測が可能となる。 そこで，MRI を 用いた GST イメージングに基づくがん診断法を目 指して， ${ }^{19} \mathrm{~F}$ MRI プローブを設計した．7-アミノ-4トリフルオロメチルクマリン（AFC）のアミノ基 にアリールスルフォニル基を導入することで ${ }^{19} \mathrm{~F}$ MRI プローブ DNs-AFC, ANs-AFC, MNs-AFC を 設計・合成した。設計した ${ }^{19} \mathrm{~F}$ MRI プローブは, GST/GSH 触媒作用によりアリールスルフォニル基 が脱離することにより, 磁場環境下の ${ }^{19} \mathrm{~F}$ の化学シ フトが移動する [Fig. 7(A)]. 同時に AFCによる 蛍光シグナルも発生することから，二重機能性を有

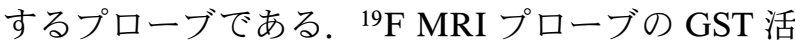
性検出能について比較したところ, 化学発光プロー ブと同様に ANs 基を用いた ANs-AFC のシグナル/ バックグラウンド比が最も大きくなることが分かつ た。そのため ANs-AFCを用いて実際に ${ }^{19} \mathrm{~F}-\mathrm{NMR}$ 測定による反応解析を行った。ANs-AFCをGST/ GSH 溶液中に添加したところ，はじめ ANs-AFC 由来の $10.88 \mathrm{ppm}$ のピークが観測された [Fig. 7 (B) ]. 時間経過とともに, $0.12 \mathrm{ppm}$ 低磁場側に生 成物 $\mathrm{AFC}$ 由来のピークがあらわれ，60 分後には ANs-AFC 由来のピークが完全に消失した，一方で, GST 非存在下では 60 分後でも反応の進行は全くみ られなかった。さらに GST を発現する大腸菌培養 液中に ANs-AFC を添加し ${ }^{19} \mathrm{~F}-\mathrm{NMR}$ 測定を検討し たところ，溶液中と同様にケミカルシフトの移動が 観察された（Fig. 8)。このピークシフトは GST を 発現しない大腸菌では観測されなかった。また，フ ローサイトメーターを用いて大腸菌内 GST を解析 したところ, GST 非存在下と比較し，3.2 倍の蛍光 シグナルを示した。 以上の結果から，ANs-AFC

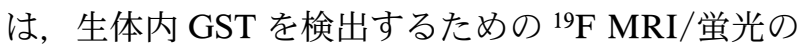
二重機能性プローブとしての利用が期待される.

抗がん剂であるドキソルビシン（doxorubicin; DOX）は，毒性・副作用が強いことががん化学療 法において問題となっている. ${ }^{31-34)}$ そこでアリール スルフォニルがん細胞で高発現する GST を利用し て，がん細胞で選択的に活性化される DOX のプロ ドラッグを開発することを試みた [Fig. 9(A)]. DOX の薬理活性発現には，糖部アミノ基が重要で あることが知られている。そこで，制御ユニット DNs をDOX のアミノ基に導入することで，活性 をマスクすることができると予想した。 プロドラッ 
(A)

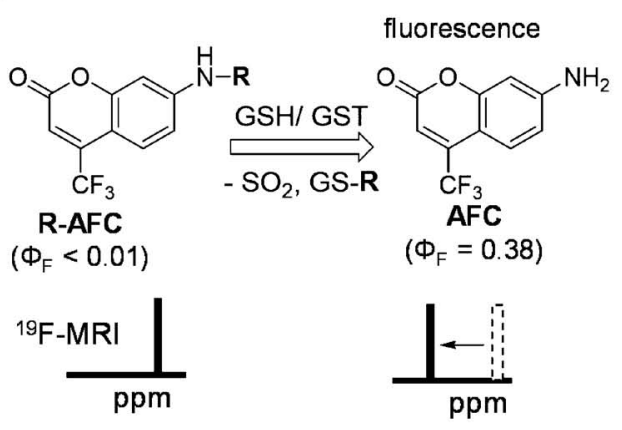

(B) with GST

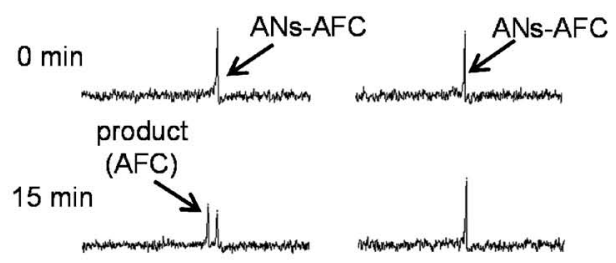

$60 \mathrm{~min}$

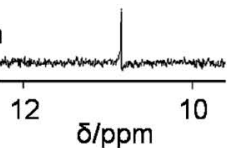

Fig. 7. (A) Mechanism of ${ }^{19}$ F-MRI Probes for GST Detection, and (B) Time Course of ${ }^{19} \mathrm{~F}$-NMR Spectra in the Presence or Absence of GST

(B) Reactions were performed in $10 \mathrm{~mm}$ PBS ( $\mathrm{pH} 7.4,1.2 \%$ DMSO as a cosolvent, $20 \% \mathrm{D}_{2} \mathrm{O}$ ) with $50 \mu \mathrm{M}$ ANs-AFC, $4 \mathrm{~mm}$ GSH, and $10 \mu \mathrm{g} / \mathrm{mL}$ sjGST for 60 $\min$ at $37^{\circ} \mathrm{C}$. The standard was TFA $(0 \mathrm{ppm})$.
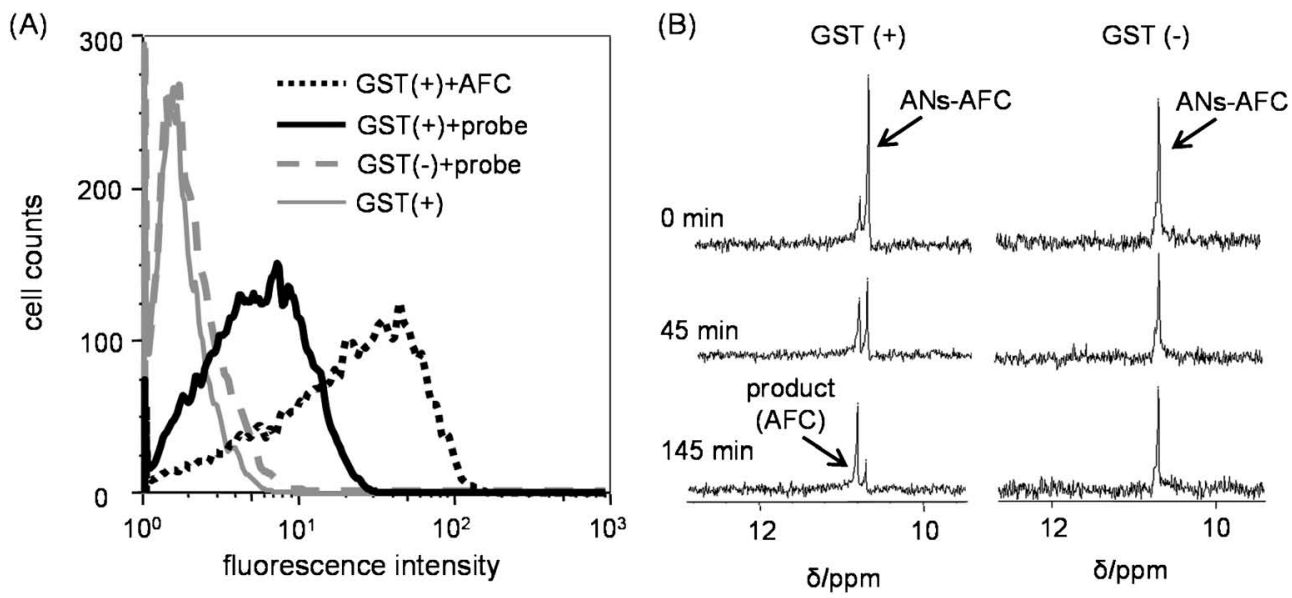

Fig. 8. (A) Detection of Intracellular GST in E. coli Cells by Flow Cytometry, and (B) Time Course of ${ }^{19}$ F-NMR Spectra in the $E$. coli of GST with Expression (+) or without Expression (-)

(A) Histograms of fluorescence intensity (constructs using flow cytometer) of ANs-AFC in E. coli cells with expression ( + ) or without expression $(-)$ of GST. Reactions were performed in E. coli cells, O.D ${ }_{600}$ was adjusted 0.8 in $10 \mathrm{~mm}$ PBS (pH 7.4), $0.2 \%$ DMSO as a cosolvent with $25 \mu \mathrm{M}$ probe and 1 mM GSH for $60 \mathrm{~min}$ at $37^{\circ} \mathrm{C}$. (B) Reactions were performed in $E$. coli cells, O.D 600 was adjusted 68 in 10 mM PBS (pH 7.4), $0.6 \%$ DMSO as a cosolvent with $300 \mu \mathrm{M}$ ANs-AFC and $1 \mathrm{~mm}$ GSH for $145 \mathrm{~min}$ at $20^{\circ} \mathrm{C}$. The standard of chemical shift was TFA $(0 \mathrm{ppm})$.

グ DNs-DOX 及び DOX をヒト細胞株に添加したと ころ, DNs-DOX は GST 活性に依存して細胞殺活 性を示すのに対して，DOX は GST 活性に関係な く細胞殺活性を示した [Fig. 9(B)]。本知見は, 活 性制御ユニット DNs を用いることで，がん細胞選 択的に薬理活性を示すプロドラッグの設計が可能で あることを示す。

\section{4. 芳香族求核置換反応を利用した高感度遺伝子}

\section{検出プローブの開発}

生きた細胞内での遺伝子検出は過剰の試薬の洗浄 等の操作を行うことができないことから，標的核酸 存在下でのみシグナルを発生させる機構が必要とな る。その 1 つに標的核酸を鋳型とした化学反応プ
ローブがある．このプローブは，標的となる核酸を 触媒として等温下でシグナルを増幅できる利点があ るため, 微量の遺伝子を検出するのに有利であると

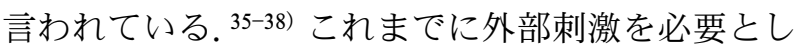
ない化学反応プローブとして, Native chemical ligation, ${ }^{39,40)}$ 加水分解反応, ${ }^{41)}$ Staudinger 反 応, $37,38,42,43)$ 転移反応, ${ }^{44,45)} S_{N} 2$ 反応 ${ }^{46,47)}$ や金属触媒 反応48）を利用した系などが報告されている。これ らのプローブを開発する際の課題としてプローブの 水溶液中での安定性 (バックグラウンド蛍光の軽減) と反応回転数の向上が挙げられる. 特に, 反応回転 数の改善は微量のシグナルを効率よく増幅するのに 重要である。一般的に化学反応プローブは Fig. 10 
(A)
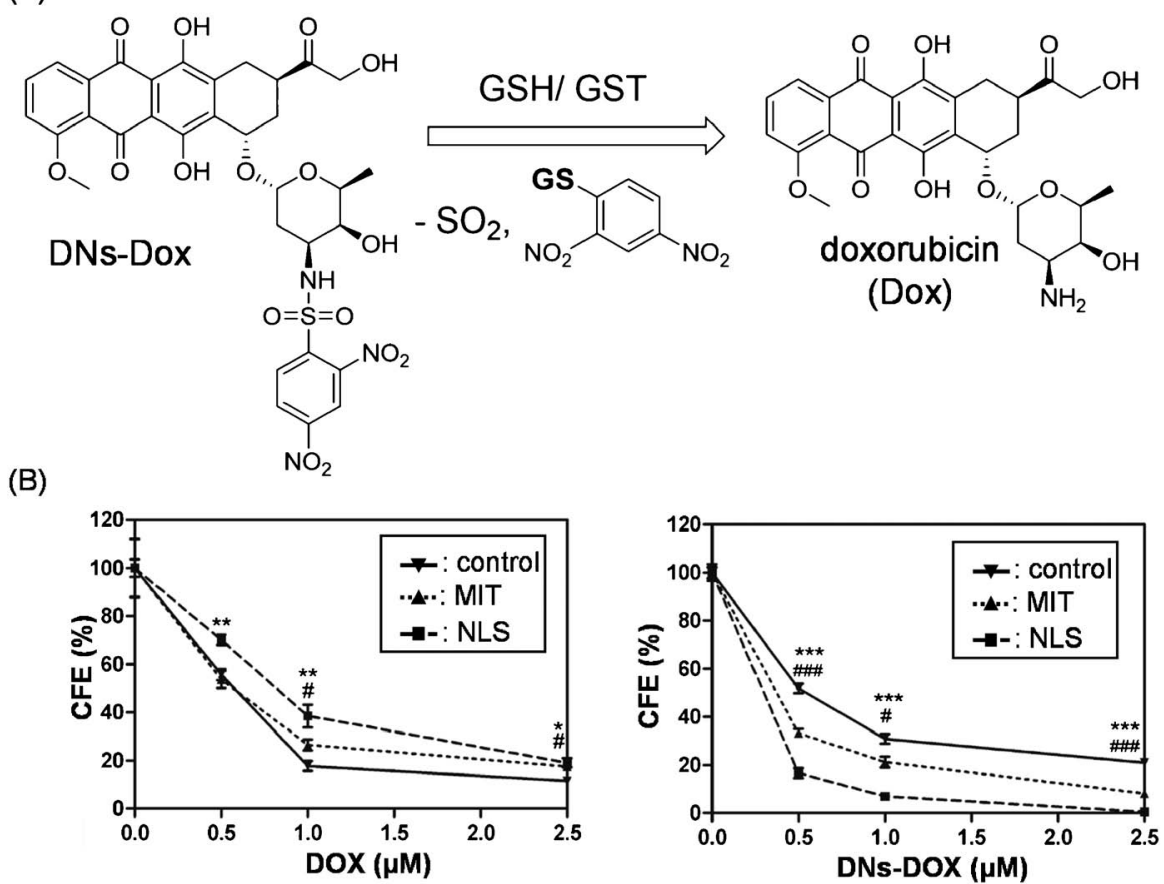

Fig. 9. (A) Prodrug Activated by GST Activity, and (B) GSTP Overexpressing V79 Cells with GSTP Accumulated in the Nucleus (NLS) and GSTP Accumulated in the Mitochondria (MIT) and Vector Control Cells were Exposed to DOX and DNs-Dox in Long Term Clonogenic Assay $(n=3)$

(B) The results are expressed as mean values \pm S.D. Significance levels for NLS $v s$. control are ${ }^{*} p<0.05$, ${ }^{* *} p<0.01$ and ${ }^{* * *} p<0.001$ and for MIT $v s$. control ${ }^{*} p$ $<0.05$, and ${ }^{\sharp \#} p<0.001$. CFE $=$ Colony Forming Efficiency.

に示すように (1) 標的遺伝子へのプローブの結合,

（2）標的遺伝子上での化学反応，（3）標的遺伝子か らのプローブのかい離の三段階を一サイクルとして シグナルを増幅する。これまでの報告例では（2) の化学反応の速度が会合やかい離の段階に比べ遅 く，サイクルを回転させるうえでの律速段階になつ ていた．そこで筆者らはこの化学反応速度を改善す ることで，高いシグナル増幅能を持つ遺伝子検出プ ローブの開発が可能であると考え，芳香族求核置換 反応による蛍光シグナルの off/on 制御の機構を利 用した遺伝子検出プローブの開発を試みた。このプ ローブは蛍光プローブと求核プローブの二本一組か らなるプローブであり，各プローブを最適化するこ とで高感度遺伝子検出を目指した. ${ }^{49)}$

はじめに, 求核基の検討を行った。求核基として はフォスホロチオエート基と，チオフェノール基の 2 種類を用いた。これらのチオールの $\mathrm{p} K_{\mathrm{a}}$ 值はいず れも 7 以下 ${ }^{50,51)}$ であることから，中性条件下で安 定なチオアニオンを形成することが期待された，蛍 光プローブには DNs 保護クマリン（DNs-AMCA） を $5^{\prime}$ 末端に修飾したものを用い, 反応の進行は保
護基が脱保護されることにより発生するクマリンの 蛍光を測定した [Fig. 11(B)]。結果，フォスホロ チオエート基を用いた PS probe を用いた場合に は，ほとんど反応は進行しなかった。一方で，チ才 フェノール基を求核基に用いた MBA probe はテン プレート存在下, DNs-AMCA probe との反応が約 20 秒で完結することが分った。しかし，MBA probe を用いた場合にはテンプレート非存在下での バックグラウンド蛍光の上昇も合わせてみられた. 微量の遺伝子を検出するためにはこのようなバック グラウンド蛍光の上昇は致命的であることから，次 に蛍光プローブの改善を試みた。 DNs 基の代わり に CNs 基を用いて蛍光プローブ CNs-AMCA probe を合成し，MBA probe との反応性を検討した [Fig. 11 (C) ] 。結果，テンプレート存在下では CNs-AMCA probe を用いた場合もDNs-AMCA probe と同様に 20 秒程度で反応の完結がみられ た. 一方で, テンプレート非存在下では, 蛍光シグ ナルの増加はほとんどみられなかった。実際， CNs-AMCA probe/MBA probe の組合せの場合, $\mathrm{S} / \mathrm{B}$ 比は 30 秒の段階で 223 倍であった［Fig. 11 


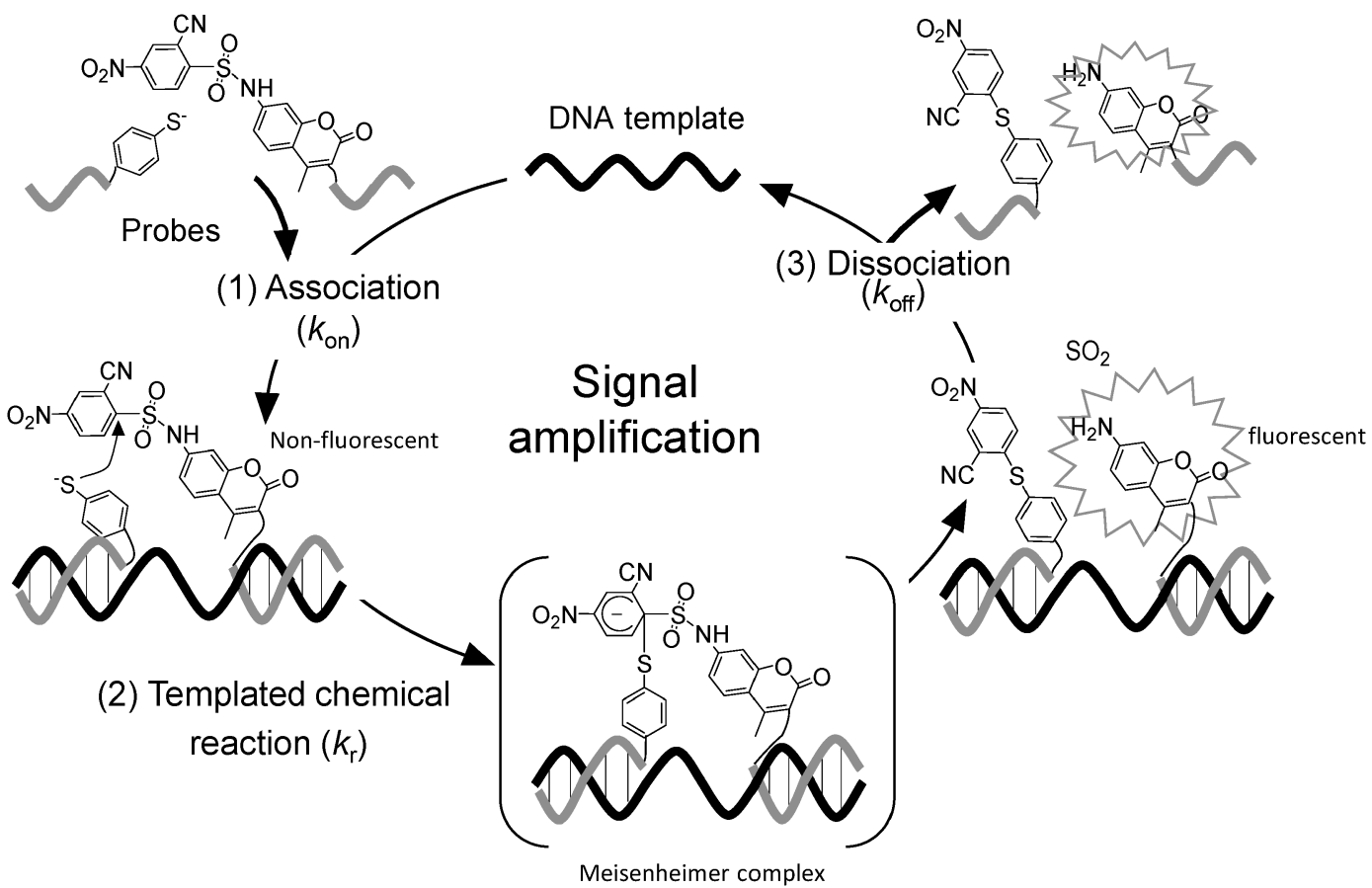

Fig. 10. Turn over Cycle of the Templated $S_{N} A r$ Reaction

(D)]。次に，得られた CNs-AMCA probe/MBA probe の組合せを用いて微量遺伝子の検出を試みた [Fig. 11(E)]．測定は反応系中で標的遺伝子に両プ ローブが同時に結合している状態が約 $50 \%$ 存在す る温度条件 $\left(22^{\circ} \mathrm{C}\right)$ で行った。結果, $0.5 \mathrm{pM}$ テン プレート存在下で，そのシグナルを 1500 倍にまで 増やすことに成功した．細胞内の 1 コピーの RNA の濃度は約 $1 \mathrm{pM}$ であることから，筆者らが開発し たプローブは十分な検出感度を持つことが明らかと なった。また，本プローブを大腸菌内に導入したと ころ，標的である $23 \mathrm{~S}$ rRNA 相補の配列を持つプ ローブを用いた場合にのみ，クマリン由来の青色蛍 光が観察された.

過去に，化学反応プローブにおけるシグナル増幅 サイクルの各段階を詳細に検討した報告はなかった ため，筆者らは開発した CNs-AMCA probe/MBA probe の各段階での速度定数を求めた。その結果を Fig. 12 に示す. CNs-AMCA probe/テンプレート 及び MBA probe/テンプレートの会合速度はそれぞ れ $51.6 \times 10^{-2} \mathrm{~s}^{-1}$ と $89.6 \times 10^{-2} \mathrm{~s}^{-1}$ ，解離速度はそ れぞれ $2.2 \times 10^{-2} \mathrm{~s}^{-1}$ と $18.6 \times 10^{-2} \mathrm{~s}^{-1}$ であった。 それに対し，反応速度はテンプレート存在下で 8.5 $\times 10^{-2} \mathrm{~s}^{-1}$ とテンプレート非存在下で $3.2 \times 10^{-6}$ $\mathrm{s}^{-1}$ と求めることができた。このことから，テンプ
レート存在下での反応速度が，テンプレートからの プローブの解離速度に非常に近い值にまで改善され ていることが見て取れる，以上のことから，CNsAMCA probe/MBA probeの組合せからなる遺伝 子検出プローブが高いシグナル増幅を達成できたの は，律速段階であった化学反応速度を改善できたこ とに起因すると考えられる.

5. テンプレート反応による分子放出プローブの 開発

創薬研究において標的細胞選択的に薬剂を作用さ せることは非常に重要である。2000 年に Ma らに よって化学反応プローブを用いた標的遺伝子選択的 な分子放出システム41) が初めて報告されて以降, これまでに複数のグループが様々な分子放出プロー ブを開発している. ${ }^{35,44,52-57)} し か し ，$ 放出された分 子が生体内で機能を発揮した報告例はほとんどな い.そこで筆者らは細胞内でタンパク質発現を誘導 するアジド基の還元反応を利用した標的遺伝子選択 的分子放出システムの構築を試みた. ${ }^{58)}$ Figure 13 にその概略を示す。このシステムでは還元剤である トリフェニルホスフィン（triphenylphosphine; TPP）を持つ TPP プローブと分子放出プローブの 二本一組のプローブを用いる．分子放出プローブは アジドメチル基で保護されており， Staudinger 反応 
(A)

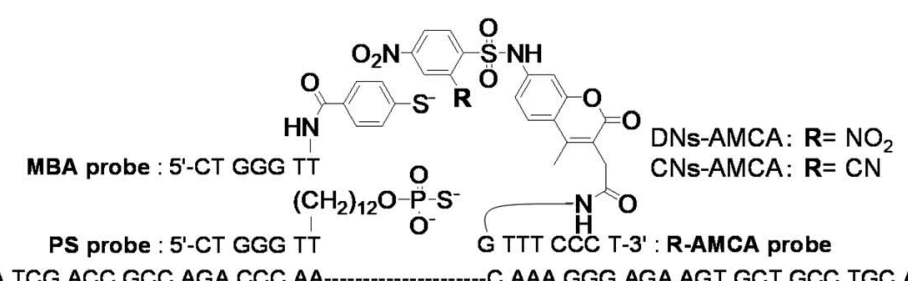

SR: 3'-ACC CTG GAA TCG ACC GCC AGA CCC AA

TTT CCC T-3' : R-AMCA probe

(B)
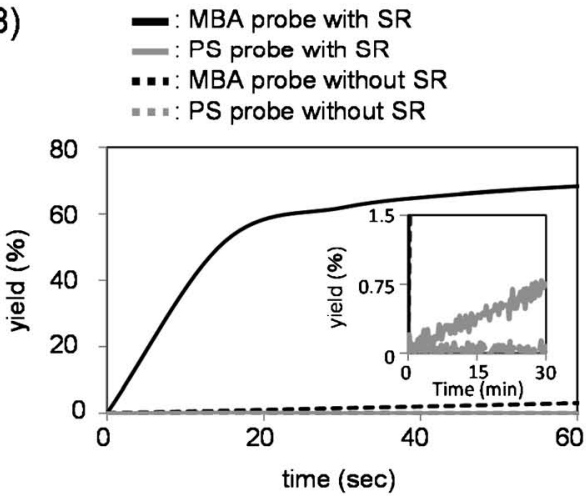

(D)

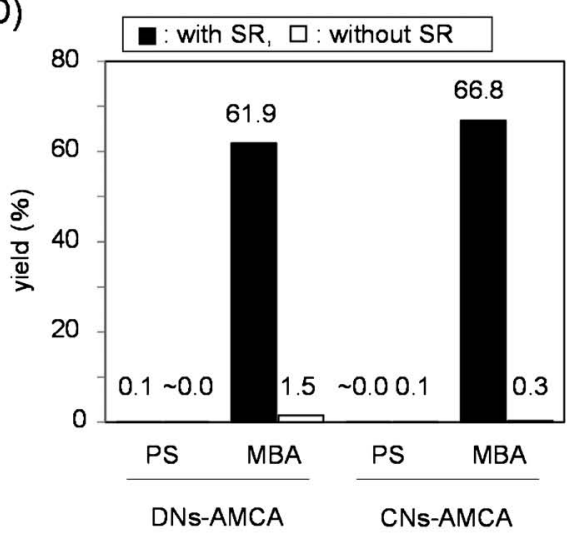

(C) $\quad$ : MBA probe with SR

- PS probe with SR

- I: MBA probe without SR " $n$ : PS probe without SR

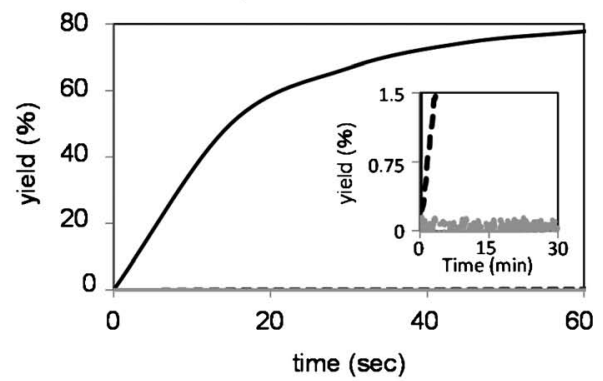

(E)

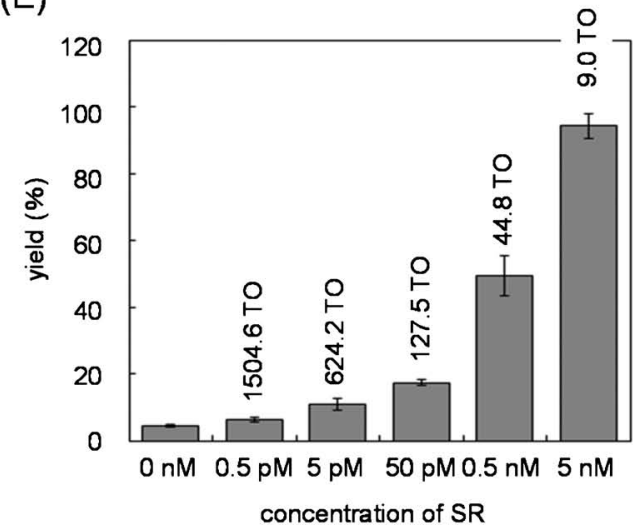

Fig. 11. DNA-templated $S_{N} A r$ Reactions

(A) Sequences of oligonucleotides used in this study. The DNs- or CNs-AMCA probe was an 8 mer ODN modified with DNs- or CNs-AMCA at the $5^{\prime}$ terminal. The nucleophilic probe was a 7 mer ODN modified with MBA or phosphorothioate at the $3^{\prime}$ terminal. The DNA targets were 52 mer ODNs (SR). The target sequence is underlined. (B), (C) Time course of the yield in the reaction between $500 \mathrm{~nm}$ MBA or PS probe and $500 \mathrm{~nm}$ R-AMCA probe (B: DNs-AMCA, C: CNsAMCA) with or without $500 \mathrm{~nm} \mathrm{SR} \mathrm{in} 20 \mathrm{~mm}$ Tris- $\mathrm{HCl}$ buffer ( $\mathrm{pH}$ 7.2) containing $100 \mathrm{~mm} \mathrm{MgCl}_{2}$ at $22^{\circ} \mathrm{C}$. Reaction was monitored by excitation at $375 \mathrm{~nm}$ and emission at $450 \mathrm{~nm}$. (D) The yield of templated reaction after $30 \mathrm{~s}$. (E) The reaction yields after $15 \mathrm{~h}$ and turnover numbers (TO). Reactions were performed $50 \mathrm{~nm}$ CNs-AMCA and MBA probe at shown SR concentrations ( $50 \mathrm{~nm}-0.5 \mathrm{pm)} \mathrm{in} \mathrm{Tris-} \mathrm{HCl}$ buffer ( $\mathrm{pH} 7.2)$ containing $100 \mathrm{~mm} \mathrm{MgCl}_{2}$ at $22^{\circ} \mathrm{C}$. The reaction yields were reported as average of values from four times.

によりこの保護基が除去されると，ついで 1,6-転移 反応が起こり結果，分子が系中に放出される．放出 分子はイソプロピル- $\beta$-チオガラクトピラノシド （IPTG）である. lac オペレーターで発現が制御さ れている GFP 発現ベクターではlacリプレッサー が IPTG と結合して lac オペレーターから外れるこ とで GFP の発現が誘導される. ${ }^{59)}$ そのため, この プローブが大腸菌内に導入された際の，標的遺伝子 に基づく分子放出について GFP の蛍光強度で評価 することができる.

まずはじめに，アジド基の還元による分子放出が
起こるかどうか, 消光剤である $p$-メチルレッド (MR）放出プローブを用いて, 試験管内で FRET の解消による蛍光の経時変化を測定することで検討 した（Fig. 14）。その結果，テンプレート非存在下 では蛍光強度は全く上昇しないのに対し，テンプ レート存在下では時間依存的に蛍光の上昇がみられ たことから，MR の放出が起こっていることが確認 できた。一方，テンプレート上に 1 つミスマッチを 含む配列を標的とした場合，蛍光の上昇は全くみら れなかったことから，この放出プローブは高い塩基 配列認識能を有することも明らかとなった。このプ 
(A)

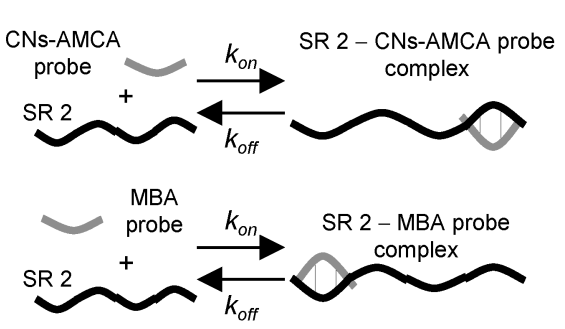

(B)

\begin{tabular}{lccccccc}
\hline & $\begin{array}{c}\mathrm{K}^{\mathrm{a}} \\
\left(\times 10^{6} \mathrm{M}^{-1}\right)\end{array}$ & $\begin{array}{c}k_{\mathrm{on}} \\
\left(\times 10^{6} \mathrm{M}^{-1} \mathrm{~s}^{-1}\right)\end{array}$ & $\begin{array}{c}k_{\mathrm{on}}{ }^{\prime} \\
\left(\times 10^{-2} \mathrm{~s}^{-1}\right)\end{array}$ & $\begin{array}{c}k_{\mathrm{off}} \mathrm{b} \\
\left(\times 10^{-2} \mathrm{~s}^{-1}\right)\end{array}$ & $\begin{array}{c}k_{\mathrm{r}}^{+} \\
\left(\times 10^{-2} \mathrm{~s}^{-1}\right)\end{array}$ & $\begin{array}{c}k_{\mathrm{r}}^{-} \\
\left(\times \mathrm{M}^{-1} \mathrm{~s}^{-1}\right)\end{array}$ & $\begin{array}{c}k_{\mathrm{r}}^{-1} \mathrm{c} \\
\left(\times 10^{-2} \mathrm{~s}^{-1}\right)\end{array}$ \\
\hline $\begin{array}{c}\text { CNs-AMCA probe } \\
+ \text { SR 2 }\end{array}$ & 47.1 & 1.0 & 51.6 & 2.2 & & & \\
$\begin{array}{c}\text { MBA probe + SR 2 } \\
\text { chemical reaction }\end{array}$ & 9.6 & 1.8 & 89.6 & 18.6 & & & \\
\hline
\end{tabular}

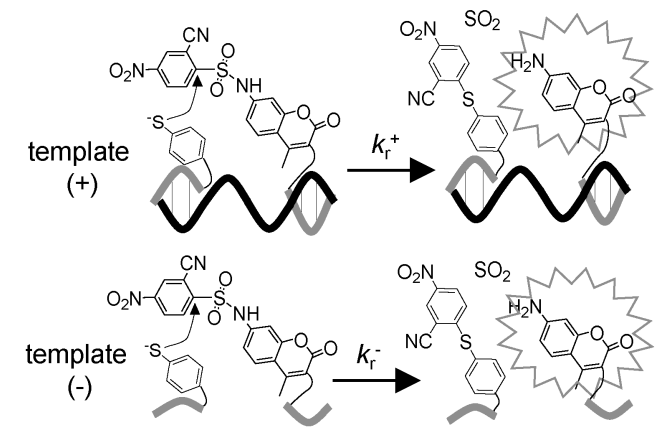

Fig. 12. (A) Scheme of Kinetic Parameters, and (B) Kinetic Parameters for the Hybridization of Each Probe and DNA-templated Reaction

(B) SR 2 was 21 mer ODN containing target sequence. a van't Hoff plot, ${ }^{\mathrm{b}} k_{\mathrm{off}}=k_{\mathrm{on}} / K,{ }^{\mathrm{c}} k_{\mathrm{r}}{ }^{-{ }^{\prime}}=k_{\mathrm{r}}{ }^{-} \times 50 \mathrm{nM}$.

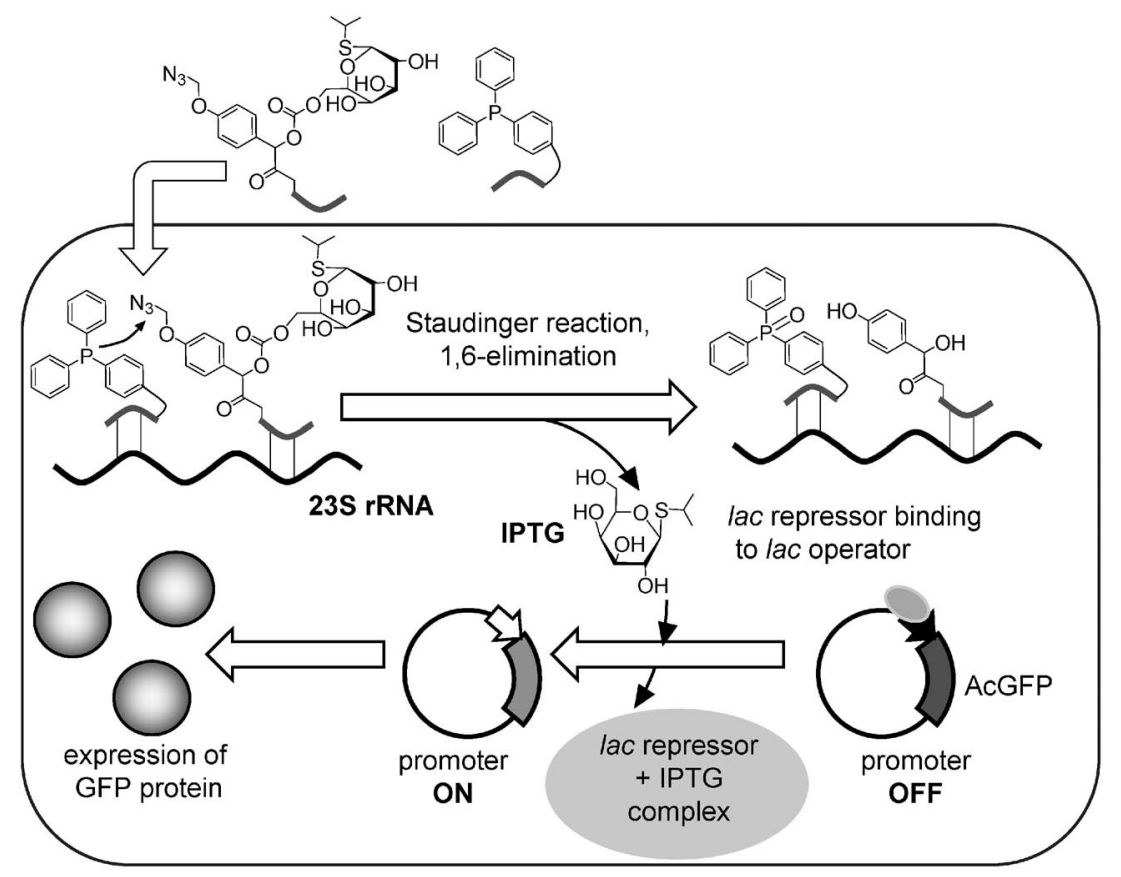

Fig. 13. IPTG Release by Templated Reaction Induced Expression of GFP Protein

ローブを大腸菌内に導入したところ，標的である 23S rRNA に相補の配列を持つプローブでのみ蛍光 の増加がみられたことから，テンプレート上での Staudinger 反応を引き金として分子放出が起きてい ることが確認できた.

最後に IPTG 放出プローブを大腸菌内に導入 し, 標的遺伝子選択的にタンパク質発現誘導が起こ 


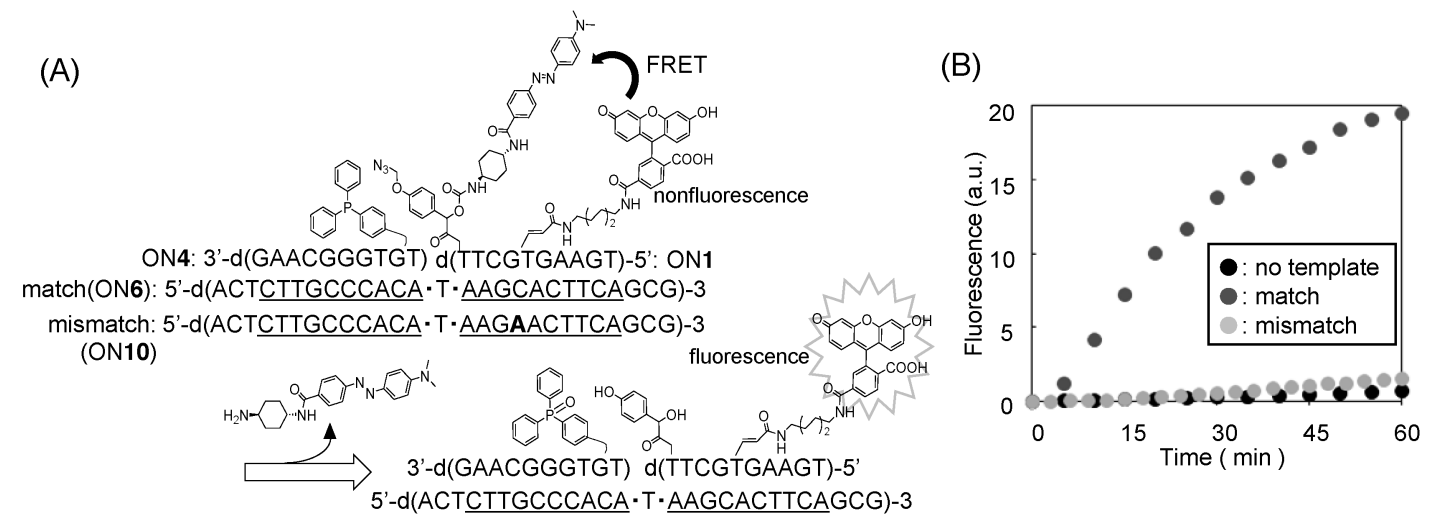

Fig. 14. (A) Sequences of Oligonucleotides Used in This Study and (B) Time Course of the Fluorescence Intensity in the Reaction

(A) The ON 1 was a 10 mer ODN modified with MR at the $3^{\prime}$ terminal. The ON 4 was a 10 mer ODN modified with TPP at the $5^{\prime}$ terminal. The target sequence is underlined. (B) Reactions were performed with $50 \mathrm{~nm} \mathrm{ON} \mathrm{1,} 250 \mathrm{~nm} \mathrm{ON} \mathrm{4,} 0$ or $50 \mathrm{~nm}$ template [match (ON 6) or mismatch (ON 10)] in $20 \mathrm{~mm}$ Tris- $\mathrm{HCl}$ buffer (pH7.2) containing $100 \mathrm{~mm} \mathrm{MgCl}_{2}$ and $1 \mu \mathrm{g} / \mathrm{mL}$ BSA. Reactions were monitored by excitation at $490 \mathrm{~nm}$ and emission at $522 \mathrm{~nm}$.

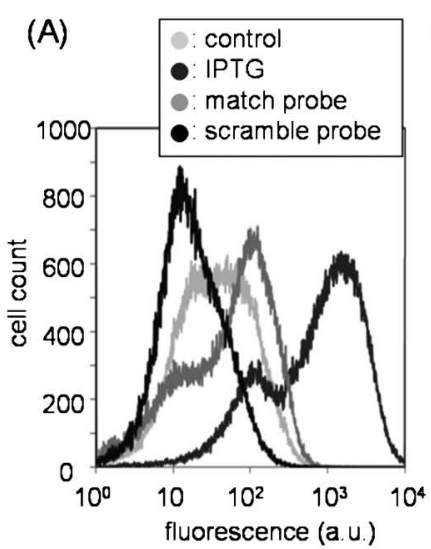

(B)

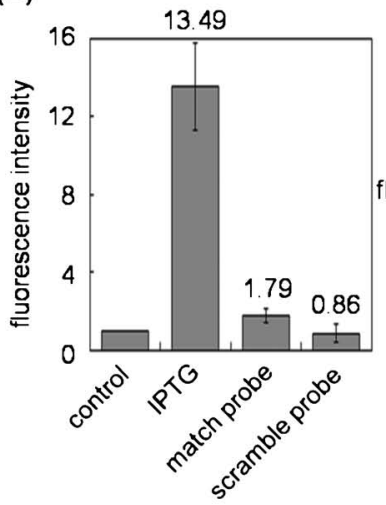

(C)

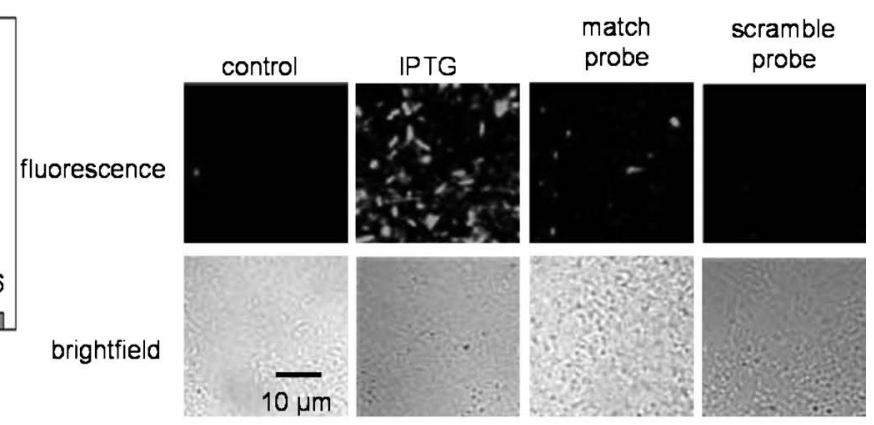

Fig. 15. Detection of the Expression of the GFP under lac Operator Control in E. coli JM109 (DE3) Cells

(A) Flow cytometry histogram showing cell-count frequency $v s$. fluorescence intensity for each probe. These histograms correspond to cells that were treated by no probe (control); by IPTG (positive control); by match probe; by scramble probes. (B) Means of fluorescence intensity and signal to background calculated from the flow cytometry histogram. (C) Imaging of GFP in E. coli JM109 (DE3). Microscope settings were as follows: excitation: 488 bandpass filter; emission: $500 / 10$ bandpass filter.

GFP を発現している細胞は観測されなかつたのに 対し，マッチ配列プローブを用いた場合には明らか な GFP の発現が観測された。以上のことからアジ ド基の還元反応を利用した放出プローブを用いて遺 伝情報に基づくタンパク質発現に成功した。

\section{6. ペプチド検出への化学反応プローブの応用}

蛍光タンパク質を用いたタンパク質標識技術は生 体内のタンパク質の発現や局在を調べるうえで重要

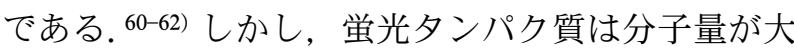
きいため, 融合タンパク質を構築した際に標的タン パク質の構造や機能に影響を及ぼす可能性があ る. ${ }^{61,62)}$ 一方，特定のタンパク質に選択的に結合す る核酸分子としてアプタマーがある，近年，このア プタマーを利用したタンパク質検出が複数のグルー

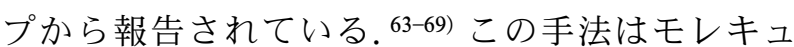

ラービーコンを利用した系66-68) とアプタマーを分 割する系63-65) の 2つに大別される。これらはいず れも FRET を用いており，発生するシグナルは標 的タンパク質と等しい，そこで，筆者らはシグナル を増幅できる化学反応プローブをタンパク質検出に 応用すべく検討を試みた. ${ }^{70)}$

HIV-1 の Rev タンパク質の一部である argininerich motif $(\mathrm{ARM})^{71,72)}$ に結合するアプタマーを分 割して, Staudinger 反応を用いた検出プローブを設 計した．検出プローブはアプタマー構造を 2 つに分 割したモチーフからなっており，一方にはアジドメ チル基で保護された蛍光化合物を，もう一方には電 子供与基であるトリフェニルホスフィンが結合して いる．これらプローブは標的タンパク質が存在する ときにのみ，元のアプタマー構造を形成し，プロー 


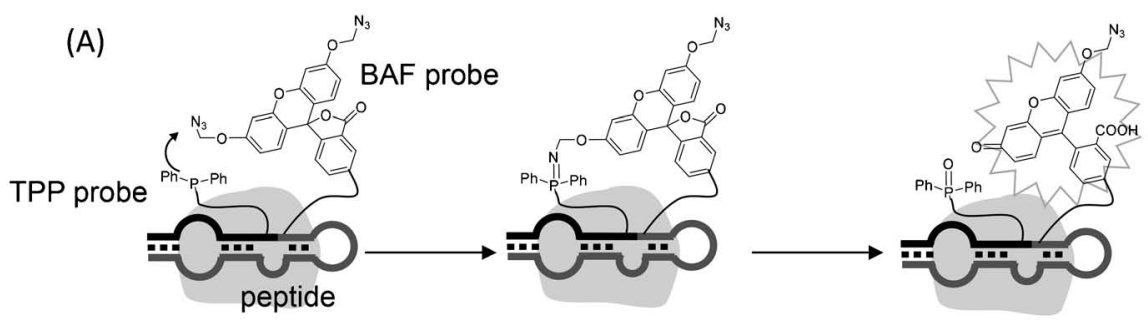

(B)

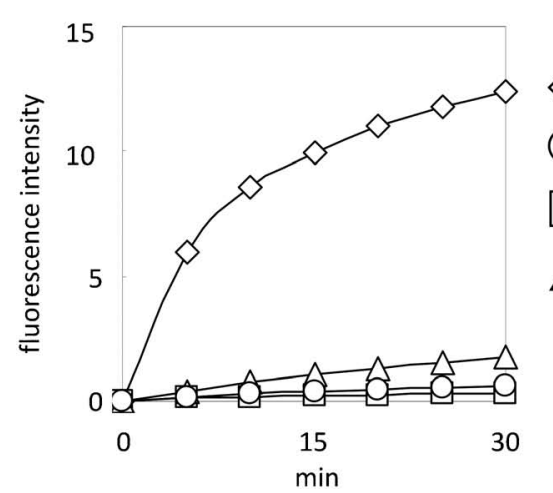

$\checkmark$ : BAF probe + TPP probe with ARM

: BAF probe with ARM

: BAF probe (mismatch) + TPP probe with ARM

BAF probe + TPP probe with peptide 1

Fig. 16. (A) Illustration of the Azidemethyl Reduction, Which Can Generate Signals in Presence of Target Peptide, and (B) Timecourse Analysis of the Fluorescence Intensity of the Reaction of BAF Probe with the TPP Probes

(B) The emission of fluorescence at $522 \mathrm{~nm}$ was monitored by excitation at $490 \mathrm{~nm}$. Reactions were performed $100 \mathrm{nM}$ BAF probe, 0 or $100 \mathrm{nM}$ TPP probe, 100 nм ARM or peptide in $50 \mathrm{~mm}$ Tris- $\mathrm{HCl}$ (pH 8.0) containing $0.13 \%$ Triton $\mathrm{x}-100$.

ブ間での還元反応が起こることで蛍光シグナルを発 生する（Fig. 16）。合成したプローブを用いて水溶 液中での ARM ペプチドの検出を試みたところ，標 的ペプチドが存在する場合, 非存在下と比較して約 19 倍の蛍光強度の増加を観察することができた。

以上のことから, 化学反応プローブがペプチド検出 にも応用可能であることを示すことができた。 しか しながら，反応系中で予期しない TPP プローブの 酸化が起こり, 十分にプローブ間での還元反応が起 こったとは言えない結果となった. 化学反応プロー ブを用いた汎用性の高いタンパク質検出プローブの 開発にはさらに反応条件や用いる化学反応種の検討 を行っていく必要がある.

\section{謝辞＼cjkstart本稿は，著者らが論文として報告した研} 究成果を中心にまとめたものです，各論文の共著者 の方々に，この場を借りて感謝の意を表させて頂き ます。特に, 名古屋大学大学院理学研究科の阿部 洋先生, 理化学研究所の伊藤嘉浩先生, 鵜澤尊規先 生, カロリンスカ研究所の Ralf Morgenstern 先生 には大変お世話になりました。 心よりお礼申し上げ ます。 利益相反＼cjkstart開示すべき利益相反はない.

\section{REFERENCES}

1) Moscow J. A., Fairchild C. R., Madden M. J., Ransom D. T., Wieand H. S., O’Brien E. E., Poplack D. G., Cossman J., Myers C. E., Cowan K. H., Cancer Res., 49, 1422-1428 (1989).

2) Chasseaud L. F., Adv. Cancer Res., 29, 175274 (1979).

3) Habig W. H., Pabst M. J., Jakoby W. B., J. Biol. Chem., 249, 7130-7139 (1974).

4) Mannervik B., Adv. Enzymol. Relat. Areas Mol. Biol., 57, 357-417 (1985).

5) Jedlitschky G., Leier I., Buchholz U., Center M., Keppler D., Cancer Res., 54, 4833-4836 (1994).

6) Ping J., Wang H., Huang M., Liu Z. S., Toxicol. Sci., 89, 438-443 (2006).

7) Zimniak P., Singh S. P., "Toxicology of Glutathione Transferases," ed. by Awasthi Y. C., CRC Press, Taylor \& Francis Group, Boca Raton, 2007, p. 11.

8) Morgenstern R., DePierre J. W., Ernster L., Biochem. Biophys. Res. Commun., 87, 657- 
663 (1979).

9) Morgenstern R., Meijer J., Depierre J. W., Ernster L., Eur. J. Biochem., 104, 167-174 (1980).

10) Morgenstern R., Svensson R., Bernat B. A., Armstrong R. N., Biochemistry, 40, 33783384 (2001).

11) Shimoji M., Aniya Y., Morgenstern R., "Toxicology of Glutathione Transferases," ed. by Awasthi Y. C., CRC Press, Taylor \& Francis Group, Boca Raton, 2007, p. 293.

12) Svensson R., Alander J., Armstrong R. N., Morgenstern R., Biochemistry, 43, 8869-8877 (2004).

13) Ålander J., Johansson K., Heuser V. D., Farebo H., Järvliden J., Abe H., Shibata A, Ito M., Ito Y., Morgenstern R., Anal. Biochem., 390, 52-56 (2009).

14) Zhang J., Shibata A., Ito M., Shuto S., Ito Y., Mannervik B., Abe H., Morgenstern R., J. Am. Chem. Soc., 133, 14109-14119 (2011).

15) Shibata A., Nakano Y., Ito M., Araki M., Zhang J., Yoshida Y., Shuto S., Mannervik B., Mogenstern R., Ito Y., Abe H., Analyst, 138, 7326-7330 (2013).

16) Keen J. H., Habig W. H., Jakoby W. B., J. Biol. Chem., 251, 6183-6188 (1976).

17) Chen W. J., Graminski G. F., Armstrong R. N., Biochemistry, 27, 647-654 (1988).

18) van der Aar E. M., Buikema D., Commandeur J. N., te Koppele J. M., van Ommen B., van Bladeren P. J., Vermeulen N. P., Xenobioti$c a, 26,143-155$ (1996).

19) Van der Aar E. M., Bouwman T., Commandeur J. N., Vermeulen N. P., Biochem J., 320, 531-540 (1996).

20) van der Aar E. M., de Groot M. J., Bouwman T., Bijloo G. J., Commandeur J. N., Vermeulen, N. P., Chem. Res. Toxicol., 10, 439-449 (1997).

21) Swain C. G., Lupton E. C., J. Am. Chem. Soc., 90, 4328-4337 (1968).

22) Prade L., Huber R., Manoharan T. H., Fahl W. E., Reuter W., Structure, 5, 1287-1295 (1997).

23) O’Dwyer P. J., LaCreta F., Nash S., Tinsley P. W., Schilder R, Clapper M. L, Tew K. D, Panting L., Litwin S., Comis R. L., Cancer Res., 51, 6059-6065 (1991).
24) Ito M., Shibata A., Zhang J., Hiroshima M., Sako Y., Nakano Y., Kojima-Aikawa K., Mannervik B., Shuto S., Ito Y., Morgenstern R., Abe H., ChemBioChem, 13, 1428-1432 (2012).

25) Johansson K., Ito M., Schophuizen C. M. S., Thengumtharayil S. M., Heuser V. D., Zhang J., Shimoji M., Vahter M., Ang W. H., Dyson P. J., Shibata A., Shuto S., Ito Y., Abe H., Morgenstern R., Mol. Pharmaceutics, 8, 1698-1708 (2011).

26) Schaap A. P., Chen T. S., Handley R. S., Desilva R., Giri B. P., Tetrahedron Lett., 28, 1155-1158 (1987).

27) Richard J. A., Jean L., Romieu A., Massonneau M., Noack-Fraissignes P., Renard P. Y., Org. Lett., 9, 4853-4855 (2007).

28) Matsumoto M., J. Photochem. Photobiol., 5, 27-53 (2004) .

29) Beck S., Koster H, Anal. Chem., 62, 22582270 (1990).

30) Ahrens E. T., Flores R., Xu H. Y., Morel P. A., Nat. Biotechnol., 23, 983-987 (2005).

31) Šimůnek T., Štěrba M., Popelová O., Adamcová M., Hrdina R., Geršl V., Pharmacol. Rep., 61, 154-171 (2009).

32) Pabla N., Dong Z., Kidney Int., 73, 994-1007 (2008)

33) Rybak L. P., Curr. Opin. Otolaryngol. Head Neck Surg., 15, 364-369 (2007).

34) McWhinney S. R., Goldberg R. M., McLeod H. L., Mol. Cancer Ther., 8, 10-16 (2009) .

35) Sando S., Kool E. T., J. Am. Chem. Soc., 124, 9686-9687 (2002).

36) Abe H., Kool E. T., Proc. Natl. Acad. Sci. USA, 103, 263-268 (2006).

37) Furukawa K., Abe H., Hibino K., Sako Y., Tsuneda S., Ito Y., Bioconjug. Chem., 20, 1026-1036 (2009).

38) Pianowski Z., Gorska K., Oswald L., Merten C. A., Winssinger N., J. Am. Chem. Soc., 131, 6492-6497 (2009).

39) Dose C., Seitz O., Org. Lett., 7, 4365-4368 (2005).

40) Dose C., Ficht S., Seitz O., Angew. Chem., Int. Ed., 45, 5369-5373 (2006).

41) Ma Z., Taylor J. S., Proc. Natl. Acad. Sci. USA, 97, 11159-11163 (2000).

42) Cai J., Li X., Yue X., Taylor J. S., J. Am. 
Chem. Soc., 126, 16324-16325 (2004).

43) Li H., Franzini R. M., Bruner C., Kool E. T., ChemBioChem, 11, 2132-2137 (2010).

44) Grossmann T. N., Seitz O., J. Am. Chem. Soc., 128, 15596-15597 (2006).

45) Grossmann T. N., Seitz O., Chem. Eur. J., 15, 6723-6730 (2009).

46) Silverman A. P., Kool E. T., Chem. Rev., 106, 3775-3789 (2006).

47) Silverman A. P., Kool E. T., Adv. Clin. Chem., 43, 79-115 (2007).

48) Franzini R. M., Kool E. T., Org. Lett., 10, 2935-2938 (2008).

49) Shibata A., Uzawa T., Nakashima Y., Ito M., Nakano Y., Shuto S., Ito Y., Abe H., J. Am. Chem. Soc., 135, 14172-14178 (2013).

50) Jaffe E. K., Cohn M., Biochemistry, 17, 652657 (1978).

51) Gough J. D., Gargano J. M., Donofrio A. E., Lees W. J., Biochemistry, 42, 11787-11797 (2003).

52) Pianowski Z. L., Winssinger N., Chem. Commun., 3820-3822 (2007).

53) Furukawa K., Abe H., Hibino K., Sako Y., Tsuneda S., Ito Y., Bioconjug. Chem., 20, 1026-1036 (2009).

54) Okamoto A., Tanabe K., Inasaki T., Saito I., Angew. Chem. Int. Ed., 42, 2502-2504 (2003).

55） Ma Z. C., Taylor J. S., Bioconjug. Chem., 14, 679-683 (2003).

56) Boll I., Krämer R., Brunner J., Mokhir A., $J$. Am. Chem. Soc., 127, 7849-7856 (2005).

57) Gorska K., Manicardi A., Barluenga S., Winssinger N., Chem. Commun., 47, 4364-4366
(2011).

58) Shibata A., Ito Y., Abe H., Chem. Commun., 49, 270-272 (2013).

59) Boos W., Schaedel P., Wallenfels K., Eur. J. Biochem., 1, 382-394 (1967) .

60) Giepmans B. N., Adams S. R., Ellisman M. H., Tsien R. Y., Science, 312, 217-224 (2006) .

61) Chen I., Ting A. Y., Curr. Opin. Biotechnol., 16, 35-40 (2005).

62) Soh N., Sensors, 8, 1004-1024 (2008).

63) Heyduk T., Heyduk E., Nat. Biotechnol., 20, 171-176 (2002).

64) Heyduk E., Knoll E., Heyduk T., Anal. Biochem., 316, 1-10 (2003).

65) Zhang S., Metelev V., Tabatadze D., Zamecnik P. C., Bogdanov A. Jr., Proc. Natl. Acad. Sci. USA, 105, 4156-4161 (2008).

66) Li J. J., Fang X., Schuster S. M., Tan W., Angew. Chem. Int. Ed. Engl., 39, 1049-1052 (2000) .

67) Wang K., Tang Z., Yang C. J., Kim Y., Fang X., Li W., Wu Y., Medley C. D., Cao Z., Li J., Colon P., Lin H., Tan W., Angew. Chem. Int. Ed. Engl., 48, 856-870 (2009) .

68) Yamamoto R., Baba T., Kumar P. K., Genes Cells, 5, 389-396 (2000).

69) Heyduk E., Heyduk T., Anal. Chem., 77, 1147-1156 (2005).

70) Shibata A., Abe H., Furukawa K., Tsuneda S., Ito Y., Chem. Pharm. Bull., 57, 1223-1226 (2009).

71) Levy M., Ellington A. D., J. Mol. Evol., 56, 607-615 (2003).

72) Wilkinson T. A., Zhu L., Hu W., Chen Y., Biochemistry, 43, 16153-16160 (2004). 